\title{
Effectiveness of pulsed radio frequency in seed quality improvement of vegetable plant species**
}

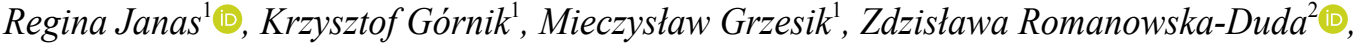 \\ and Bert van Duijn ${ }^{3,4}$ \\ ${ }^{1}$ Department of Nursery and Seed Science, Research Institute of Horticulture, Konstytucji 3 Maja 1/3, 96-100 Skierniewice, Poland \\ ${ }^{2}$ Laboratory of Plant Ecophysiology, Faculty of Biology and Envoronmental Protection, University of Łódź, Banacha 12/16, \\ 92-237 Łódź, Poland \\ ${ }^{3}$ Institute of Biology Leiden, Sylviusweg 72, 2333 BE, Leiden, The Netherlands \\ ${ }^{4}$ Fytagoras BV, Sylviusweg 72, 2333 BE Leiden, The Netherlands
}

Received September 27, 2018; accepted April 25, 2019

\begin{abstract}
The most significant problem, in ecological vegetable seed production, is low, capacity which is mainly caused by high rates of seed infection with fungi and a shortage of effective biological agents to eliminate pathogens. Therefore, proecological methods of seed quality enhancement are being researched, with the aim of increasing the profitability of seed production by improving the seed sowing value. The aim of the work was to evaluate the effectiveness of pulsed radio frequency on the seed quality of selected vegetable cultivars. The results obtained from research conducted in laboratory, greenhouse and field conditions indicate the protective effect of pulsed radio frequency treatment of seeds by a reduction in the incidence of beetroot, lettuce and garden dill seed-borne fungi, and an improvement in their health status and germination capacity. The presowing application of pulsed radio frequency resulted in a $60-80 \%$ reduction of seed infestation with fungi, depending on the plant species. This treatment improved the dynamics of seed germination, plant emergence, growth, and increased the chlorophyll content and gas exchange in leaves. The most beneficial results were obtained in beetroot, in which the problem of seed production is associated with a high rate of seed infestation with mycoflora and the presence of germination inhibitors in the seed coat. The results indicate the high efficiency of the applied pulsed radio frequency and its usefulness in ecological and integrated seed production.

Keyw ords: seeds, lettuce, beetroot, garden dill, pulsed radio frequency, health status
\end{abstract}

*Corresponding author e-mail: Regina.Janas@inhort.pl

**This work was carried out under the multiannual program "Actions to improve the competitiveness and innovation of the horticultural sector, taking into account food quality and safety and environmental protection", financed by the Ministry of Agriculture and Rural Development in Poland (2014-2018).

\section{INTRODUCTION}

The development of modern agriculture and the related propagation of the principles of the rational use of natural environment resources has necessitated the search for safe methods of increasing crop yields and their quality. In the seed production of vegetable crops, especially in ecological systems, the most significant problem is the high rate of seed infestation by fungi, which results in poor seed germination capacity and a decrease in yield, and thereby causes the low economic profitability of production (Janas, 2009, 2013).

High quality seeds and proper seed presowing treatment are some of the most important yield factors. Seeds of high quality should germinate up to $100 \%$ of the time, be less sensitive to stress, store well, and produce fast growing plants, even in adverse environmental conditions (Grzesik and Janas, 2014; Janas, 2009, 2013).

Many chemical, physical and physiological methods for seed improvement are well-known, at present (Andreoli and Khan, 2000). The best known and most widely used in practice are the chemical methods associated with seed treatment by various substances (seed dressings, growth regulators, etc.), which pollute the environment and may be harmful to humans and animals. Some active substances can also penetrate inside the seeds and modify their chemical composition, they may also pollute the soil environment.

(C) 2019 Institute of Agrophysics, Polish Academy of Sciences 
Thus, in integrated plant production, the principle of eliminating chemical agents and replacing them with biological ones has been introduced. The production of organic vegetables requires the use of organic seeds, which means that they are derived not only from organic production but are also exclusively treated biologically. The limited availability of biological agents for seed dressing necessitates the use of complex biological, non-destructive and environmentally friendly methods of seed enhancement to improve their sowing value, uniformity and rate of emergence as well as plant yield. Therefore, in recent years, more attention has been paid to some physical factors that have a positive effect on the seed quality of crop plants (Dorna at al., 2010; Hołubowicz et al., 2014).

One of the ecological and physical methods that may be used in seed improvement is the stimulation of seed germination with pulsed radio frequency (PRF). The PRF method is derived from its use in interventional pain management in humans, at present, there is a lack of knowledge concerning its use in seed quality improvement. Presowing treatment with PRF improved the seed germination capacity of apple seeds (Grzesik at al., 2017). The application of low frequency magnetic fields increased seed germination capacity and the vigour of seedling emergence in the field, it also increased the onion bulb root length (Kubisz et al., 2012; Hołubowicz et al., 2014) and the growth of tomato plants (Efthimiadou et al., 2014).

The aim of the study was to evaluate the effectiveness of the presowing treatment of lettuce, beetroot and garden dill seeds with pulsed radio frequency in the categories of improving their health status, germination capacity, the dynamics of seedling emergence and plant growth, as well as the possibility of its implementation in organic seed production.

\section{MATERIALS AND METHODS}

The research was conducted on lettuce (Lactuca sativa L.), beetroot (Beta vulgaris L. subsp. vulgaris) and garden dill (Anethum graveolens L.) seeds of the 'Oleńka', 'Rywal' and 'Kronos' cultivar, respectively. The seeds were purchased from the seed company POLAN (Poland), and were kept at $15^{\circ} \mathrm{C}$ and $30 \%$ relative humidity until the initiation of the experiments.

The seeds were moistened up to a $35 \%$ moisture content in air-tight glass bottles for $4 \mathrm{~h}$ in minimal amounts of distilled water at $20^{\circ} \mathrm{C}$. After $4 \mathrm{~h}$ the seeds were subjected to pulsed radio frequency (PRF) for 120,30 or $60 \mathrm{~min}$, at a voltage of 5 or $25 \mathrm{~V}$, a pulse repetition rate of 2 or $4 \mathrm{~Hz}$ (pulses per second) and with a pulse duration of 10 or $20 \mathrm{~ms}$. PRF was applied using an RFG 3C PLUS lesion generator (Radionics, Burlington, MA, U.S.A). The generator, designed for medical use, was a radio-frequency power source equipped with pulse modulation and a provision for setting the exposure time, pulse width, and pulse repetition frequency, as well as the voltage supplied to parallel-plate electrodes. The layers of wetted seeds were placed in a plexiglass container between two metal electrodes that tightly adhered to the seeds. The distance between the electrodes was $12 \mathrm{~mm}$ and the electrode PRF surface area was $13 \times 17 \mathrm{~cm}$. The electrodes were connected to the apparatus emitting the PRF using the parameters above. After PRF treatments, the number and dynamics of the germinated seeds as well as the health status, emergence, physiological activity and growth of the plants were evaluated. The seeds not treated with PRF were the control.

Seeds from each experimental variant were seeded in three repetitions, 100 seeds in each, into Petri dishes on distilled water moistened filter paper with a basis weight of $250 \mathrm{~g} \mathrm{~m}^{-2}$. The germination of seeds at $20^{\circ} \mathrm{C}$ was monitored every day to estimate the dynamics and percentage of their germination. A seed was regarded as germinated when the radicle emerged from the pericarp.

The effectiveness of the PRF treatment was also assessed by a laboratory evaluation of the root and plant growth using the Phytotoxkit microbiotest (Persoone and Vangheluwe, 2000). Ten moistened seeds of each vegetable species were placed on separate filter papers, which were then transferred to the test plates. The test plates were closed and placed vertically in a metal tripod. The seedlings were grown over a $16 / 8 \mathrm{~h}$ photoperiod at $20^{\circ} \mathrm{C}$ under fluorescent white light. All assays were performed in four replications for each experimental variant of the three plant species. Root and shoot length measurements were made daily with a ruler.

Another portion of the PRF-treated seeds were sown in pots and transferred to greenhouse conditions where seedling emergence, plant growth and height were assessed. The third part of such treated seeds were sown in the field, where the same parameters as in the greenhouse experiment were investigated.

The health status of the seeds of lettuce, beetroot and garden dill were assessed after PRF treatment using two methods: agar-potato medium (PDA) and a paper test (TB). The seeds were sown on PDA medium in Petri dishes, 5 seeds in a dish, a total of 250 seeds of each plant species. The seeds were incubated at a temperature of $20^{\circ} \mathrm{C}$ for 7-10 days depending on the plant species and subsequently illumined with NUV light. The garden dill seeds were additionally frozen according to ISTA rules (International Rules for Seed Testing, 2002-2007). In the paper test (TB), mycological analyses were performed analogously with the difference that the seeds were sown on filter paper moistened with distilled water. A microbiological evaluation was conducted using Leica microscopy. Mycological analyses concerned all of the fungi that infested the seeds. Their pathogenicity was not assessed.

Gas exchange in leaves: the net photosynthetic rate (PN), transpiration (E), stomatal conductance (Gs), and intercellular $\mathrm{CO}_{2}$ concentration $(\mathrm{Ci})$ were measured using 
portable photosynthesis measurement system TPS-2 (PP Systems, USA) (Grzesik et al., 2017). The measurements were carried out under greenhouse conditions on fully developed leaves during morning hours (08:00-11:00 h). The temperature was between $20-25^{\circ} \mathrm{C}$, air humidity between $70-80 \%$, and light intensity between $1100-1300 \mu \mathrm{mol}$ (photon) $\mathrm{m}^{-2} \mathrm{~s}^{-1}$.

The index of chlorophyll content (CCI) in the leaves was evaluated nondestructively using a portable Minolta SPAD-502 chlorophyll meter (Konica Minolta, Japan) and expressed in SPAD units (Grzesik et al., 2017). Five readings were obtained from individual leaves. During measurements with the SPAD-502, the sensor head was shaded with the operator's own body as recommended by the manufacturer to prevent direct sunlight from reaching the instrument.

The experiments concerning PRF treatments and the determination of germination capacity as well as the dynamics of the germination, root lengths and seedling heights, the dynamics of seedling emergence, plant height, gas exchange and the index of chlorophyll content were performed in three series and in three repetitions for each experimental variant. The least significant differences (LSD) were calculated at the level $\mathrm{p}=0.05$ for all experimental data. The means of the chosen parameters were grouped by employing Duncan's test at the $\alpha=0.05$ significance level.

\section{RESULTS AND DISCUSSION}

The growing area of vegetable crops in ecological systems requires the optimization of the organic production of seeds with a particular emphasis on improving germination capacity and the health of the seed material, as well as accelerating the rate of germination and plant emergence. Therefore, there is a growing interest in the use of various seed-processing treatments and their implementation in agriculture (Dorna et al., 2010; Sousa Araújo at al., 2016). Kubala et al. (2013) indicated the strategic role of seed conditioning in their quality improvement. Janas $(2009,2013)$ emphasized the role of biological and physical methods in improving the seed-sowing value of selected species of horticultural plants. The results of the presented study confirm the beneficial effect of the presowing treatments of lettuce, beetroot and garden dill seeds with PRF on their health, germination capacity and plant emergence enhancement.

The results of the presented research, carried out under laboratory conditions and then verified in greenhouse and field conditions, indicate the high efficiency of pulsed radio frequency (PRF) in improving the health and germination capacity of seeds as well as plant emergence and growth (Tables 1-3, Figs 1-9). The treatment with PRF of the imbibed seeds positively influenced the germination dynamics, number of germinated seeds, dynamics of emergence and the growth of the above-ground parts of plants and

Table 1. Effects of 'Oleńka' lettuce seed treatment with pulsed radio frequency on their rate of infection with mycoflora (\% in relation to total isolates)

\begin{tabular}{|c|c|c|c|c|}
\hline \multirow{3}{*}{ Mycoflora } & \multicolumn{4}{|c|}{ PRF parameters used in lettuce seeds } \\
\hline & Control & $120 / 5 / 2 / 10$ & $30 / 25 / 4 / 20$ & $60 / 25 / 4 / 20$ \\
\hline & \multicolumn{4}{|c|}{ Infection of seeds with mycoflora ( $\%$ in relation to total isolates) } \\
\hline Alternaria spp. & 46.0 & 17.5 & 14.0 & 10.5 \\
\hline Ulocladium sp. & 3.0 & 1.5 & 0.9 & 0.8 \\
\hline Botrytis cinerea Pers & 2.5 & 1.0 & 0.5 & 1.0 \\
\hline Fusarium sp. & 1.5 & 1.0 & 0.0 & 0.8 \\
\hline Cladosporium sp. & 4.5 & 1.2 & 0.5 & 1.4 \\
\hline $\begin{array}{l}\text { Epicoccum purpurascens Ehrenb. } \\
\text { Ex Schlecht }\end{array}$ & 3.5 & 2.0 & 1.3 & 1.8 \\
\hline Stemphylium botryosum Wallr. & 2.9 & 1.1 & 0.5 & 2.0 \\
\hline Trichothecium roseum Pers. & 1.3 & 0.9 & 0.5 & 0.0 \\
\hline Sclerotinia sclerotiorum (Lib.) de Bary & 2.0 & 2.0 & 1.0 & 0.5 \\
\hline Verticillium sp. & 1.5 & 0.9 & 0.5 & 0.0 \\
\hline Bipolaris sorokiniana (Sacc. in Sorok.) & 1.8 & 1.0 & 0.4 & 1.0 \\
\hline Penicillium sp. & 3.1 & 2.0 & 0.5 & 1.5 \\
\hline Rhizopus nigricans Ehr. & 3.0 & 2.0 & 0.8 & 3.0 \\
\hline$\%$ of infected seeds & 51.5 & 19.5 & 15.2 & 11.0 \\
\hline
\end{tabular}

Seeds were subjected to PFR exposure for 120,30 or $60 \mathrm{~min}, 5$ or $25 \mathrm{~V}, 2$ or $4 \mathrm{~Hz}$ and 10 or $20 \mathrm{~ms}$. 
Table 2. Effect of 'Rywal' beetroot seed treatment with pulsed radio frequency on their rate of infection with mycoflora (\% in relation to total isolates)

\begin{tabular}{|c|c|c|c|c|}
\hline \multirow{3}{*}{ Mycoflora } & \multicolumn{4}{|c|}{ PRF parameters used in beetroot seeds } \\
\hline & Control & $120 / 5 / 2 / 10$ & $30 / 25 / 4 / 20$ & $60 / 25 / 4 / 20$ \\
\hline & \multicolumn{4}{|c|}{ Infection of seeds with mycoflora (\% in relation to total isolates) } \\
\hline Alternaria spp. & 39.0 & 11.0 & 14.2 & 9.2 \\
\hline Aspergillus spp. & 2.2 & 1.0 & 0.7 & 0.3 \\
\hline Chaetomium spp. & 1.5 & 0.5 & 0.0 & 0.0 \\
\hline Cladosporium herbarum (Pers.) Link ex Fr. & 2.6 & 1.0 & 1.0 & 0.0 \\
\hline Epicoccum purpurascens Ehrenb. Ex Schlecht & 3.0 & 1.0 & 1.2 & 1.0 \\
\hline Fusarium spp. & 3.5 & 0.9 & 0.6 & 0.4 \\
\hline Phoma betae Frank & 2.0 & 0.5 & 0.0 & 0.0 \\
\hline Mucor spp. & 1.5 & 1.0 & 0.0 & 0.0 \\
\hline Penicillium spp. & 2.5 & 0.8 & 0.8 & 0.5 \\
\hline Rhizopus nigricans Ehr. & 4.1 & 1.2 & 1.0 & 0.4 \\
\hline Trichoderma spp. & 3.2 & 1.5 & 0.5 & 0.7 \\
\hline Cercospora beticola Sacc. & 2.5 & 0.5 & 0.6 & 0.0 \\
\hline$\%$ of infected seeds & 41.0 & 12.8 & 15.0 & 9.5 \\
\hline
\end{tabular}

Explanations as in Table 1.

Table 3. Effect of 'Kronos' garden dill seed treatment with pulsed radio frequency on their rate of infection with mycoflora (\% in relation to total isolates)

\begin{tabular}{|c|c|c|c|c|}
\hline \multirow{3}{*}{ Mycoflora } & \multicolumn{4}{|c|}{ PRF parameters used in garden dill seeds } \\
\hline & Control & $120 / 5 / 2 / 10$ & $30 / 25 / 4 / 20$ & $60 / 25 / 4 / 20$ \\
\hline & \multicolumn{4}{|c|}{ Infection of seeds with mycoflora ( $\%$ in relation to total isolates) } \\
\hline Alternaria alternata (Fr.) Keissler & 70.5 & 18.5 & 25.5 & 20.0 \\
\hline Alternaria radicina Meier, Drechsl. \& Eddy & 4.2 & 1.6 & 2.2 & 2.0 \\
\hline Alternaria dauci (Kühn) Groves \& Skolko & 2.5 & 0.0 & 0.5 & 0.0 \\
\hline Drechslera sp. & 2.0 & 0.5 & 0.8 & 0.8 \\
\hline Epicoccum purpurascens Ehrenb. Ex Schlecht & 4.5 & 0.8 & 1.5 & 1.0 \\
\hline Penicillium sp. & 2.8 & 0.5 & 0.9 & 0.5 \\
\hline Cladosporium cladosporioides (Fres.) de Vries & 2.0 & 0.5 & 1.0 & 0.6 \\
\hline Fusarium spp. & 2.5 & 1.2 & 0.8 & 0.5 \\
\hline Stemphylium botryosum Wallr. & 2.4 & 1.5 & 0.0 & 0.6 \\
\hline Gonatobotrys sp. & 1.0 & 0.5 & 0.5 & 0.5 \\
\hline Aspergillus sp. & 3.6 & 0.8 & 1.2 & 0.8 \\
\hline$\%$ of infected seeds & 76.0 & 25.0 & 27.5 & 24.5 \\
\hline
\end{tabular}

Explanations as in Table 1.

roots, as well as gas exchange and the chlorophyll content in leaves. However, it was found that the degree of germination improvement and the growth of roots and hypocotyls depended on the PRF parameters, exhibited by voltage (V), pulse repetition rate $(\mathrm{Hz})$, pulse duration $(\mathrm{ms})$ and time of exposure, as well as the species of plants whose seeds were treated. The treatments with PRF for 1 hour, at a constant voltage of $25 \mathrm{~V}$, pulse repetition rates of $4 \mathrm{~Hz}$ and a pulse duration of $20 \mathrm{~ms}$ increased seed temperature by up to $40^{\circ} \mathrm{C}$ and were most successful treatments in improving their health status, germination capacity and plant growth. The application of PRF resulted in the most beneficial effects on the health, germination capacity and growth of beetroot and, to a slightly lesser extent, garden dill and lettuce (Figs 1-9). The results obtained refer to the earlier studies of Grzesik et al. (2017), who showed the beneficial effects of PRF on seed germination and the growth of apple seedlings. It is believed that PRF acts in a similar way as a magnetic field. Moreover, Chua at al. (2011) reported that biological changes in tissues during PRF treatment may occur due to 

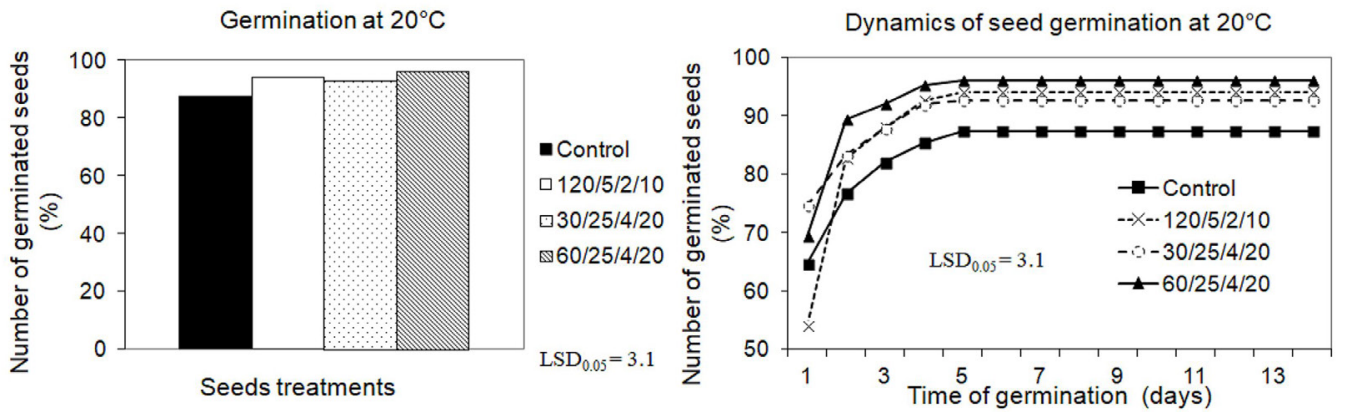

Fig. 1. Effect of 'Oleńka' lettuce seed treatment with pulsed radio frequency (PRF) on the germination capacity (after 13 days) and dynamics of seed germination at $20^{\circ} \mathrm{C}$. The seeds were subjected to PFR exposure for 120,30 or $60 \mathrm{~min}, 5$ or $25 \mathrm{~V}, 2$ or $4 \mathrm{~Hz}$ and 10 or $20 \mathrm{~ms}$ pulse interval.
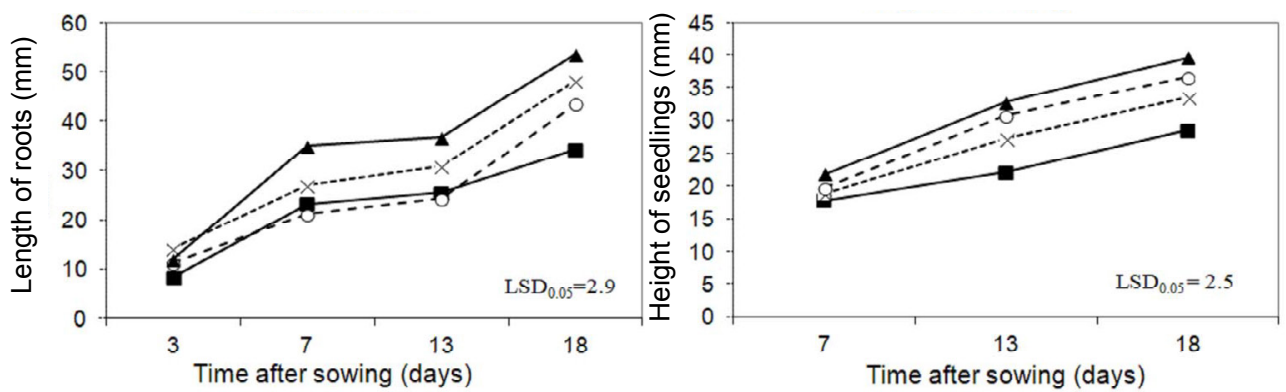

Fig. 2. Effect of 'Oleńka' lettuce seed treatment with pulsed radio frequency (PRF) on the dynamics of root growth and the height of seedlings in Phytotoxkit plates at $20^{\circ} \mathrm{C}$ in greenhouse conditions. Explanations and legend as in Fig. 1.
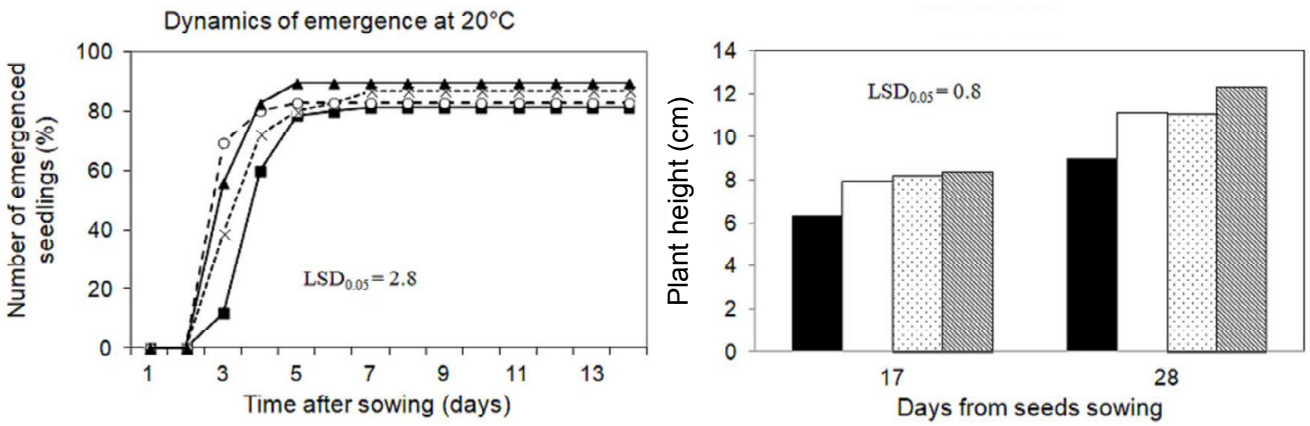

Fig. 3. Effect of 'Oleńka' lettuce seed treatment with pulsed radio frequency (PRF) on the emergence dynamics and height of seedlings in the field. Explanations and legend as in Fig. 1.
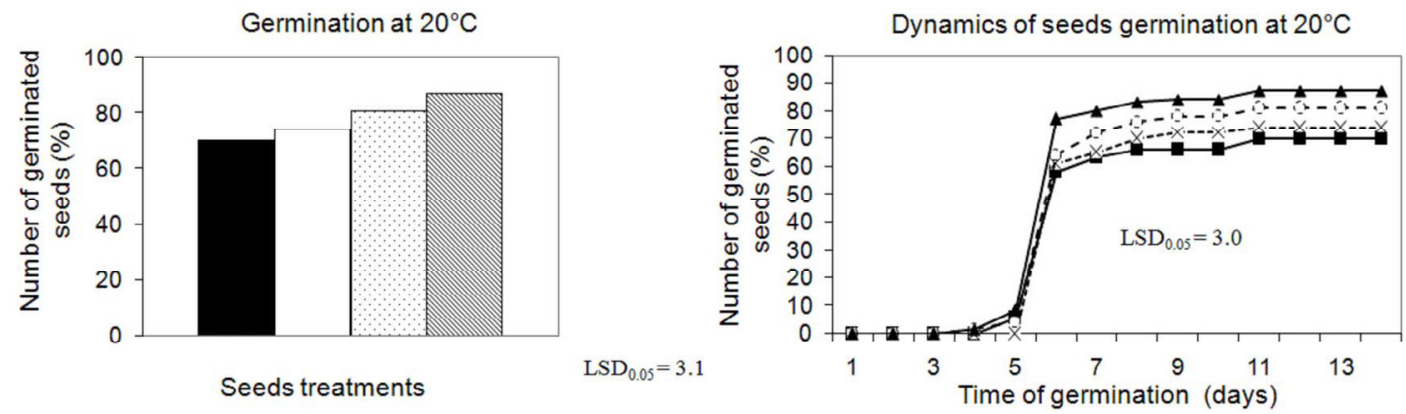

Fig. 4. Effect of 'Rywal' beetroot seed treatment with pulsed radio frequency (PRF) on the germination capacity (after 13 days) and dynamics of seed germination at $20^{\circ} \mathrm{C}$. Explanations and legend as in Fig. 1. 

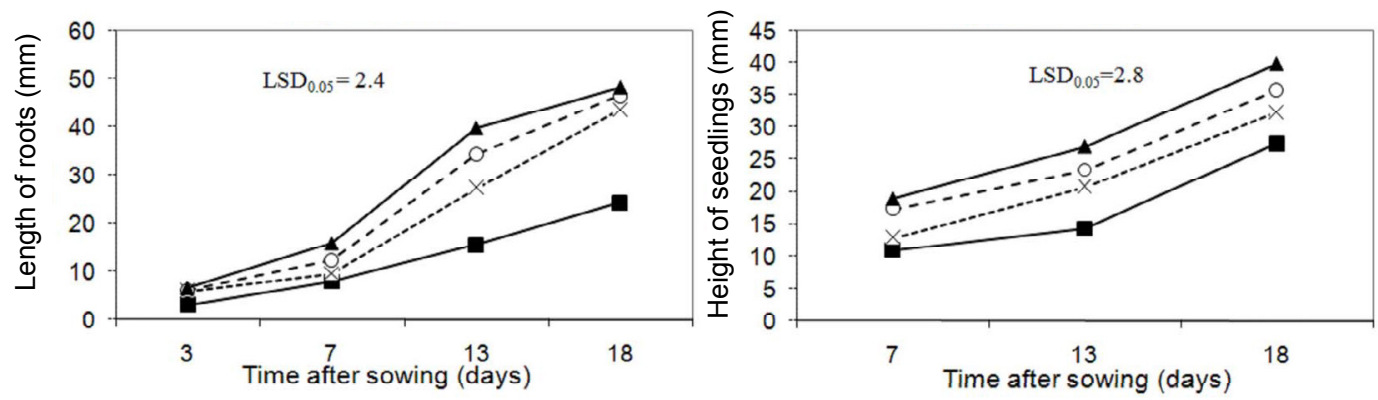

Fig. 5. Effect of 'Rywal' beetroot seed treatment with pulsed radio frequency (PRF) on the dynamics of root growth and height of plants in Phytotoxkit plates at $20^{\circ} \mathrm{C}$ in greenhouse conditions. Explanations and legend as in Fig. 1.
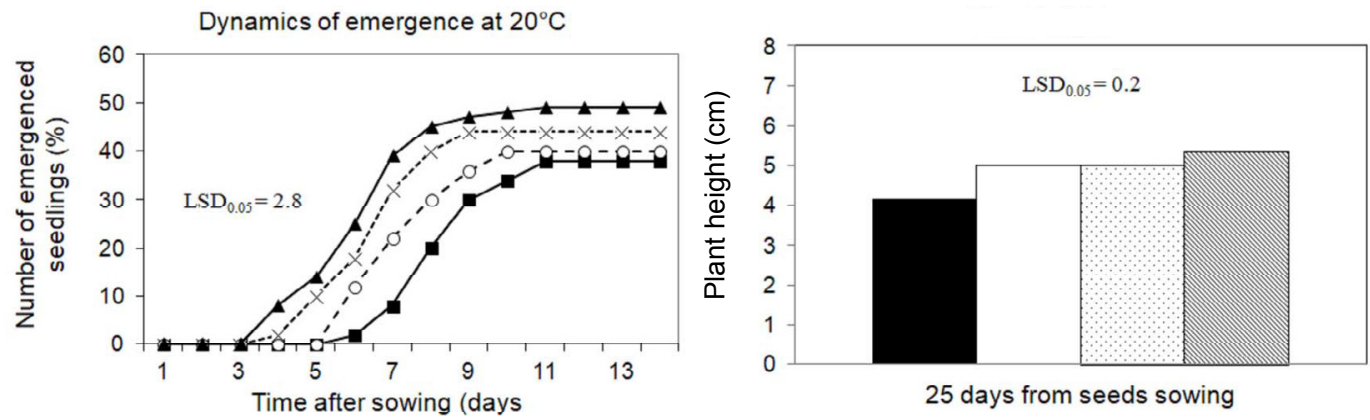

Fig. 6. Effect of 'Rywal' beetroot seed treatment with pulsed radio frequency (PRF) on the emergence dynamics and height of seedlings emergence in the field. Explanations and legend as in Fig. 1.
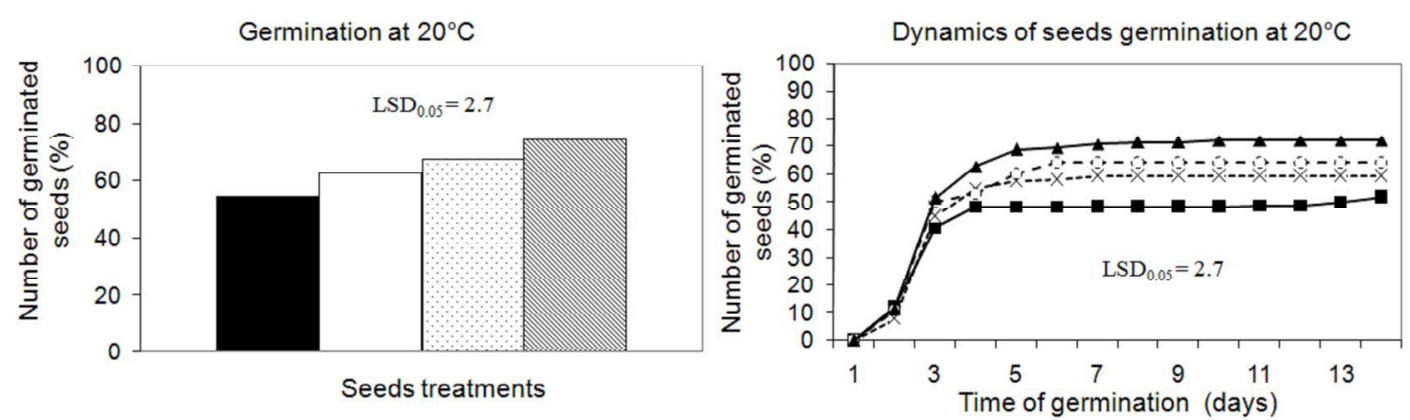

Fig. 7. Effect of 'Kronos' garden dill seed treatment with pulsed radio frequency (PRF) on the germination capacity (after 13 days) and dynamics of seed germination at $20^{\circ} \mathrm{C}$. Explanations and legend as in Fig. 1.
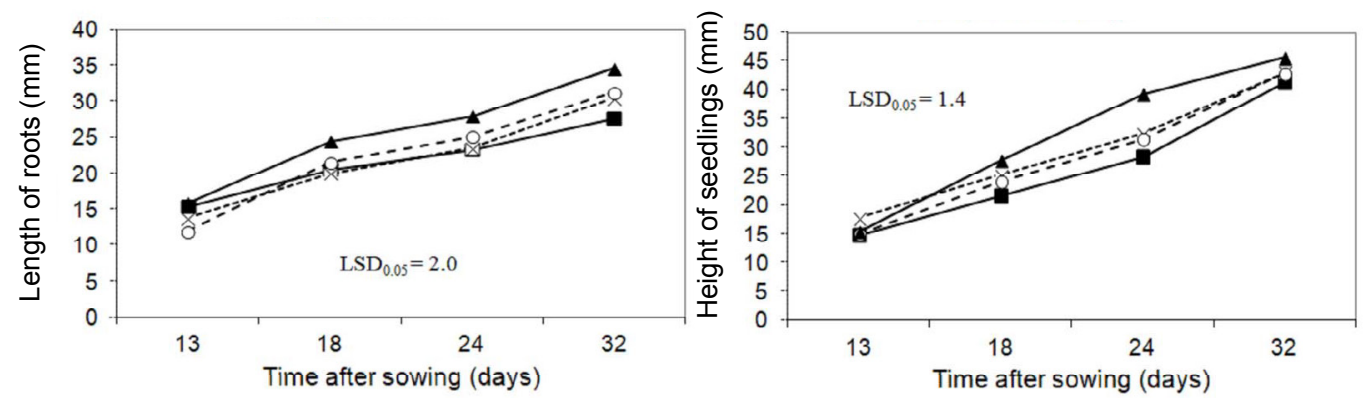

Fig. 8. Effect of 'Kronos' garden dill seed treatment with pulsed radio frequency (PRF) on the dynamics of root growth and height of plants in Phytotoxkit plates at $20^{\circ} \mathrm{C}$ in greenhouse conditions. Explanations and legend as in Fig. 1. 

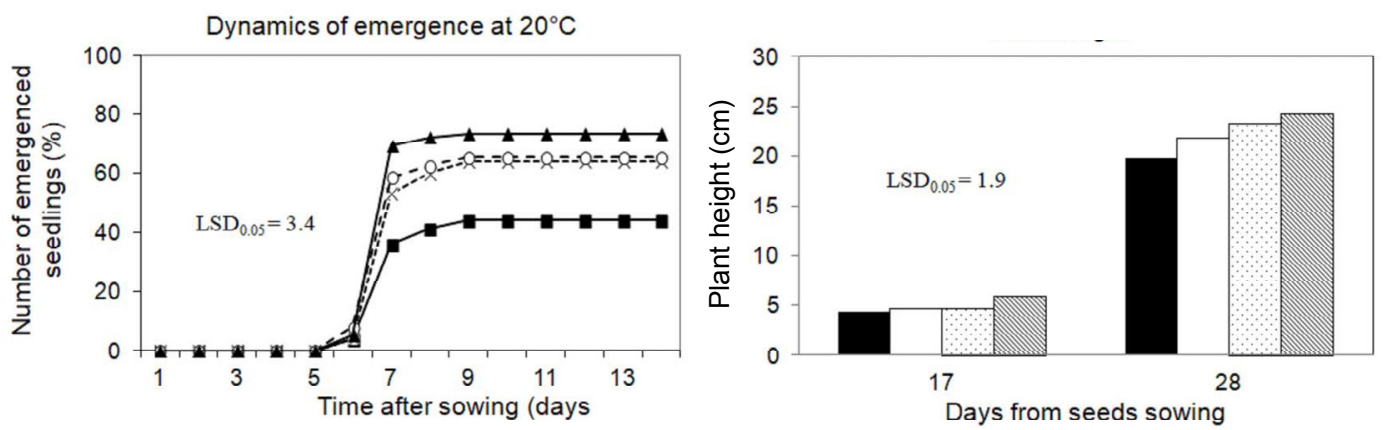

Fig. 9. Effect of 'Kronos' garden dill seed treatment with pulsed radio frequency (PFR) on the emergence dynamics and height of seedlings emergence in the field. Explanations and legend as in Fig. 1.

thermal effects and the high intensity of electric fields, or as a result of both. This finding is in line with our studies in which the longer exposure to PRF and the use of the highest parameters also generated heat. According to Chua et al. (2011), electric fields may have significant effects on cells because they can induce changes in transmembrane potentials. In humans, when used for medicinal purposes, PRF causes the formation of hydrogen peroxide $\left(\mathrm{H}_{2} \mathrm{O}_{2}\right)$ in tissues, which is characterized by, among other characteristics, its disinfectant and oxidizing properties. It is likely that similar results were caused by the use of PRF in moist seeds, however this phenomenon was not tested in the experiments presented.

The microbiological analysis of both treated and untreated (control) lettuce, garden dill and beetroot seeds, demonstrate the protective effect of seed treatment with PRF against fungi. Treatment with PRF reduced the infection rate of seeds with fungi by $50-70 \%$, depending on the species and the PRF parameters used (Tables 1-3). This indicates that PRF is an effective treatment used to reduce mycoflora, whose infestation of seeds determines their sowing value. Thus, this technique may be used to improve the quality of seeds. The results obtained have also shown that the correct selection and adjustment of the PRF parameters to the requirements of individual species and cultivars determines the validity of these methods being implemented in integrated and organic seed production.

The highest level of effectiveness of PRF in improving beetroot seed germination capacity could be the result of the greatest reduction of seed infestation with fungi, which occurred in the most intensive treatment. An additional factor favourably influencing the germination capacity of this species may be the impact of PRF on the microbial-derived inhibitors contained in the seed coats. The seeds of garden dill and lettuce were less infested with this mycoflora. The results obtained are in line with Dorna's at al. (2010) research showing the positive impact of a permanent magnetic field together with the shielding effect of an alternating electric field on the germination capacity of carrot seeds and a decrease in the percentage of infected seedlings. The research presented indicates that PRF can play a key role in limiting the infection of seeds with mycoflora and improving their health status. The reduction of seed colonization by fungal infection results in improved seed quality, improved germination capacity and accelerated the emergence and growth of the plants obtained. For this reason, further work is required to improve the method of PRF seed treatment in order to enhance their health, which may be useful in organic plant production.

Improved health status, and improved germination capacity of seeds and plant growth under the influence of PRF was associated with a higher rate of gas exchange and index of chlorophyll content in the leaves, depending on the PRF parameters used and the species of the tested plants. Under the influence of the seed treatment with PRF, the index of chlorophyll content in the leaves of the obtained plants and the activity of net photosynthesis, transpiration and stomatal conductance increased, while the content of intercellular $\mathrm{CO}_{2}$ decreased proportionally to the aforementioned parameters (Table 4). Similar relationships were found in apple seedlings obtained from seeds treated with PRF (Grzesik et al., 2017).

To date, the research data concerning the effect of PRF on seed health, germination capacity and plant development are limited and the majority of them concern interventional pain management in humans because this method was developed for medical purposes, as was the apparatus used in this study. The presented studies indicate that the use of PRF improved the quality of the seeds, including the reduction of fungal infestation, this finding is in line with those of our previous studies with apple seeds (Grzesik at al., 2017). To date, in the ecological production of plants, the improvement of germination has been attempted through the treatment of seeds with some physical factors, including a magnetic field and light. Among the physical methods available, "magneto-priming" and irradiation with microwaves or ionizing radiation are the most promising presowing seed treatments. "Magneto-priming" is based on the application of magnetic fields and is described as an eco-friendly, inexpensive, non-invasive technique with proven beneficial effects on seed germination capacity, vigour and crop yield (Sousa Araújo at al., 2016). As indicated by Grzesiuk and Kulka (1986), the physical methods, to which PRF belongs, have a comprehensive effect on crop 
Table 4. Gas exchange and the index of chlorophyll content in lettuce, beetroot and garden dill leaves of plants derived from seeds exposed to pulsed radio frequency

\begin{tabular}{|c|c|c|c|c|c|}
\hline Treatments & $\begin{array}{l}\text { Net photosynthesis } \\
\left(\mu \mathrm{m} \mathrm{CO} \mathrm{C}_{2}^{-2} \mathrm{~s}^{-1}\right)\end{array}$ & $\begin{array}{c}\text { Transpiration } \\
\left(\mathrm{mmol} \mathrm{H}_{2} \mathrm{O} \mathrm{m}^{-2} \mathrm{~s}^{-1}\right)\end{array}$ & $\begin{array}{c}\text { Stomatal } \\
\text { conductance } \\
\left(\mathrm{mmol} \mathrm{m}^{-2} \mathrm{~s}^{-1}\right)\end{array}$ & $\begin{array}{c}\text { Intercellular } \\
\text { concentration of } \mathrm{CO}_{2} \\
\left(\mu \mathrm{mol} \mathrm{CO} \mathrm{CO}_{2} \text { air } \mathrm{mol}^{-1}\right)\end{array}$ & $\begin{array}{c}\text { Index chlorophyll } \\
\text { content } \\
\text { (SPAD) }\end{array}$ \\
\hline \multicolumn{6}{|c|}{ Lettuce 'Oleńka' } \\
\hline Control & $1.15 \mathrm{a}$ & $0.78 \mathrm{a}$ & $256.0 \mathrm{a}$ & $395.0 \mathrm{~d}$ & $24.06 \mathrm{a}$ \\
\hline PFR 120/5/2/10 & $1.56 \mathrm{~b}$ & $1.16 \mathrm{~b}$ & $312.0 \mathrm{~b}$ & $343.0 \mathrm{c}$ & $25.20 \mathrm{~b}$ \\
\hline PFR 30/25/4/20 & $2.04 \mathrm{c}$ & $1.46 \mathrm{c}$ & $297.0 \mathrm{c}$ & $331.0 \mathrm{~b}$ & $25.39 \mathrm{~b}$ \\
\hline PFR 60/25/4/20 & $2.40 \mathrm{~d}$ & $1.75 \mathrm{~d}$ & $330.0 \mathrm{~d}$ & $306.0 \mathrm{a}$ & $25.46 \mathrm{~b}$ \\
\hline \multicolumn{6}{|c|}{ Beetroot 'Rywal' } \\
\hline Control & $1.18 \mathrm{a}$ & $0.85 \mathrm{a}$ & $273 \mathrm{a}$ & $226 \mathrm{c}$ & $24.12 \mathrm{a}$ \\
\hline PFR 120/5/2/10 & $1.72 \mathrm{~b}$ & $1.21 \mathrm{~b}$ & $289 \mathrm{a}$ & $220 \mathrm{c}$ & $25.63 \mathrm{~b}$ \\
\hline PFR 30/25/4/20 & $2.09 \mathrm{c}$ & $1.42 \mathrm{c}$ & $292 \mathrm{ab}$ & $201 \mathrm{~b}$ & $25.81 \mathrm{~b}$ \\
\hline PFR 60/25/4/20 & $2.64 \mathrm{~d}$ & $1.59 \mathrm{~d}$ & $312 \mathrm{~b}$ & $187 \mathrm{a}$ & $25.83 \mathrm{~b}$ \\
\hline \multicolumn{6}{|c|}{ Garden dill 'Kronos' } \\
\hline Control & $1.20 \mathrm{a}$ & $0.90 \mathrm{a}$ & $280.0 \mathrm{a}$ & $340.0 \mathrm{~d}$ & $24.01 \mathrm{a}$ \\
\hline PFR 120/5/2/10 & $1.70 \mathrm{~b}$ & $1.20 \mathrm{~b}$ & $291.0 \mathrm{a}$ & $325.0 \mathrm{c}$ & $25.93 \mathrm{~b}$ \\
\hline PFR 30/25/4/20 & $2.05 \mathrm{c}$ & $1.38 \mathrm{c}$ & $293.0 \mathrm{a}$ & $307.0 \mathrm{~b}$ & $26.07 \mathrm{~b}$ \\
\hline PFR 60/25/4/20 & $2.55 \mathrm{~d}$ & $1.70 \mathrm{~d}$ & $330.0 \mathrm{~b}$ & $293.0 \mathrm{a}$ & $29.13 \mathrm{c}$ \\
\hline
\end{tabular}

Data marked with the same letters, within the column, are not significantly different, according to the Duncan multiple range test at an alpha level of 0.05 .

seeds and they stimulate the enzymatic processes to the greatest extent. This was confirmed by Podleśny's research (Podleśny, 2002, Podleśny et al., 2001), who demonstrated the stimulatory effect of magnetic field and laser radiation on the activity of amylolytic enzymes in germinating faba been seeds and the beneficial impact the treatment had on yields and on the formation of some favourable morphological traits. According to Lebedev et al. (1977) a permanent magnetic field may affect the photochemical activity of chloroplasts. A pulsed electromagnetic field, which was used as a presowing treatment for 10-15 min, enhanced tomato plant growth (Efthimiadou et al., 2014). Pittman (1971) and Pittman et al. (1977) demonstrated the positive impact of applying a magnetic field to increase the activity of amylolytic enzymes in germinating barley grains and on the yields of barley, wheat and oat grains. The seeds treated with a magnetic field absorbed moisture more rapidly and germinated earlier, which resulted in earlier and morevigorous plant emergence (Hirota et al., 1999; Hołubowicz et al., 2014). In general, it is assumed that a low-intensity magnetic field has a positive effect on germination and plant development, while a high-intensity field reduces germination capacity and limits plant development. The presented studies have demonstrated the beneficial effects of PRF on the reduction of seed infection with fungi, which resulted in the improvement of sowing value. Therefore, further research should be conducted in order to optimize the PRF parameters and to explore the possibility of using this method as an alternative to chemical seed disinfection.

\section{CONCLUSIONS}

1. Presowing treatments with pulsed radio frequency is a promising, non-invasive, non-chemical and environmentally friendly method that may be used to improve the health status and vigour of vegetable species seeds, produced in ecological and integrated systems.

2. The elaborated parameters of pulsed radio frequency favourably affected the health, dynamics and the number of germinated seeds produced, as well as the emergence and growth of beetroot, garden dill and lettuce plants. For this reason, they may be recommended in the organic production of the plant species studied.

3. The evaluated parameters and methods of the presowing seed treatments of selected vegetable species with pulsed radio frequency, allow organic crops to achieve the high standards of seed quality, which are required in EU countries (Council Directive 202/55 / EC of 13 June 2002 on the marketing of material for sowing vegetables).

Conflict of interest: The Authors do not declare a conflict of interest. 


\section{REFERENCES}

Andreoli C. and Khan A.A., 2000. Integration of physiological, chemical and biological seed treatments to barley, wheat and oats in Southern Alberta. Can. J. Plant Sci., 57, 37-45.

Chua N.H.L., Vissers K.C., and Sluijter M.E., 2011. Pulsed radiofrequency treatment in interventional pain management: mechanisms and potential indications - a review. Acta Neurochir., 153(4), 763-771. https://doi.org/10.1007/ s00701-010-0881-5

Dorna H., Górski R., Szopińska D., Tylkowska K., Jurga J., Wosiński S., and Tomczak M., 2010. Effects of a permanent magnetic field together with the shielding of an alternating electric field on carrot seed vigour and germination. Ecol. Chem. Eng. S., 17(1), 53-61.

Efthimiadou A., Katsenios N., Karkanis A., Papastylianou P., Triantafyllidis V., Travlos I., and Bilalis D.J., 2014. Effects of presowing pulsed electromagnetic treatment of tomato seed on growth, yield, and lycopene content. Sci. World J., 2014: 369745. https://doi.org/10.1155/2014/369745

Grzesik M., Górnik K., Janas R., Lewandowki M., Romanowska-Duda M., and van Duijn B., 2017. High efficiency stratification of apple cultivar Ligol seed dormancy by phytohormones, heat shock and pulsed radio frequency. J. Plant Physiol., 219, 81-90. https://doi. org/10.1016/j.jplph.2017.09.007

Grzesik M. and Janas R., 2014. Physiological method for improving seed germination and seedling emergence of root parsley in organic systems. J. Res. Appl. Agric. Eng., 59(3), 80-86.

Grzesiuk S. and Kulka K., 1996. Seed Physiology and Biochemistry (in Polish). PWRiL, Warsaw, Poland.

Hirota N., Nakagawa J., and Kitazawa K., 1999. Effects of a magnetic field on the germination of plants. J. Appl. Physics, 85(8), 5717-5719. https://doi.org/10.1063/1.370262

Hołubowicz R., Kubisz L., Gauza M., Tong Y., and HojanJezierska D., 2014. Effect of low frequency magnetic field (LFMF) on the germination of seeds and selected useful characters of onion (Allium cepa L.). Not. Bot. Hort. Agrob., 42(1), 168-172. https://doi.org/10.15835/nbha4219131

International Rules for Seed Testing, 2002-2007. Seed health testing methods. International Seed Testing Association, Bassersdorf. https://doi.org/10.15258/istarules.2015.07
Janas R., 2009. Possibilities of using effective microorganisms in organic crop production systems. Problemy Inżynierii Rolniczej, 3(65), 111-119.

Janas R., 2013. Evaluation of the possibility of improving the healthiness of fennel seeds grown in ecological systems. J. Agric. Appli. Res., 58(3), 226-228.

Kubala S., Wojtyla Ł., and Garnczarska M., 2013. Conditioning as a strategy for seed quality improvement. Postępy Biologii Komórki, 40(2), 215-230.

Kubisz L., Hołubowicz R., Li H., Gauza M., Hojan-Jezierska D., and Jaroszyk P., 2012. Effect of low frequency magnetic field (LFMF) on the germination of seeds of onion (Allium cepa L.). Acta Phys. Pol., 121A, 49-53. https://doi.org/10.12693/aphyspola.121.a-49

Lebedev I.S., Litvinenko L.G., and Shiyan L.T., 1977. After effect of a permanent magnetic field on photochemical activity of chroloplasts. Sov. Plant Physiol., 24, 394-395.

Persoone G. and Vangheluwe M.L., 2000. Toxicity determination of the sediments of the river Seine in France by application of a battery of microbiotests (Eds G. Persoone, C. Janssen, W. De Coen) In: New Microbiotests for Routine Toxicity Screening and Biomonitoring. Kluwer Academic, New York, 427-439. https://doi.org/10.1007/978-1-46154289-6 47

Pittman U.J., 1971. Biomagnetic responses in germinating malting barley. Can. J. Plant Sci., 51, 64-65.

https://doi.org/10.4141/cjps71-012

Pittman U.J., Carefoot J.M., Ormrod D.P., 1977. Effect of magnetic seed treatment on yield of plants. J. Applied Physics, 85(8), 5717-5719.

Podleśny J., 2002. Effect of laser irradiation on the biochemical changes in seeds and the accumulation of dry matter in the faba bean. Int. Agrophysics, 16, 209-213.

Podleśny J., Pietruszewski S., Podleśna A., 2001. Effectiveness of magnetic biostimulation of faba bean seeds cultivated under field experiment conditions. Int. Agrophysics, 18, 65-71.

Sousa Araújo S., Paparella S., Dondi D., Bentivoglio A., Carbonera D., and Balestrazzi A., 2016. Physical methods for seed invigoration: Advantages and challenges in seed technology. Front. Plant Sci., 7, 646.

https://doi.org/10.3389/fpls.2016.00646 